\title{
Efficacy of Hydrogen Peroxide on Postharvest Quality of White Button Mushroom
}

\author{
M. A. Sharaf-Eldin* and A. Geösel** \\ *Kafrelsheikh University, Faculty of Agriculture, Department of \\ Horticulture, Egypt and ${ }^{* *}$ Department of Vegetable and \\ Mushroom Growing, Faculty of Horticulture Science, Corvinus \\ University of Budapest, Hungary.
}

\begin{abstract}
WSHROOM quickly loses its quality due to susceptible to 1 browning, degradation of composition and microbial spoilage after harvesting and during marketing. Hydrogen peroxide is classified as generally regarded as safe for use in food, fruits and vegetables. It could be used for its properties as a bleaching and antimicrobial agent. The quality evaluation was studied during storage of fresh white button mushroom (Agaricusbisporus). Mushrooms were immersed after harvesting in 1, 2 or $4 \%$ of hydrogen peroxide comparing to immerse in water (control). The results showed that hydrogen peroxide treatments were effective for keeping eating quality, nutritional value, sensory attributes and microbial safety during storage due to decrease the degradation in colour, composition and hardness as well as reducing weight loss and microbial load. At the end of storage period, 2\% $\mathrm{H}_{2} \mathrm{O}_{2}$ decreased browning index by $45 \%$, relative membrane permeability by $24 \%$ and weight loss by $15 \%$ compared to the control. Immersing mushrooms in $2 \% \mathrm{H}_{2} \mathrm{O}_{2}$ also increased whiteness, dry matter, total soluble solids, protein and hardness. Lower molds and yeasts count by $23 \%$ and total bacterial count by $21 \%$ than the control were obtained. The sensory evaluation at the end of storage period indicated that $2 \% \mathrm{H}_{2} \mathrm{O}_{2}$ treatment had better colour, texture and general acceptance than the control.
\end{abstract}

Keywords: Agaricusbisporus, $\mathrm{H}_{2} \mathrm{O}_{2}$, Storage, Colour, Composition, Weight loss, Microbial activity.

Mushrooms are a good source of good quality protein. FAO distinguishes mushrooms as the right source of protein to fight protein malnutrition in the cereal-dependent developing countries (FAO, 2009). These are very low-calorie and being low in fat, however desirable fat devoid of cholesterol, these make an ideal diet for the heart patients. These are also rich in vitamin B-12, folic acid and iron which reported to maintain haemoglobin level. Mushrooms are suited to those suffering from hyperacidity and constipation due to the very high fibre and alkaline elements content. Many mushrooms possess significant medicinal 
attributes like hypocholesterolemic, hypoglycemic, hypotensive, anti-oxidant and hepatoprotective properties (Rai and Arumuganathan, 2008). For the high medicinal and nutritional value, the developing and poor countries are in need to expand mushroom production with good postharvest practices.

Postharvest losses are usually high in most of the horticultural crops and mushrooms are considered as one of the highest (Farber et al., 2003). Mushrooms even after harvesting continue to grow, respire, mature and senesce resulting in veil-opening, browning, weight loss, wilting and finally in decay. Visual quality is the most important factor affecting retail fresh mushroom trades. Consumers prefer purchasing Agaricus (white button) mushrooms with bright white, free of casing material or other unwanted particulate contaminants clinging to the mushroom surface, without wilting appearance and free of brown blotches (Das et al., 2010). Mushrooms immediately start to soften after harvest which are known to have a very short shelf-life and susceptible to browning and moisture loss as a result of the high respiration rate, enzymatic activity and weak cell wall, especially at high storage temperature conditions (Zivanovic \& Buescher, 2004, Lespinard et al., 2009 and Mohapatra et al., 2010). The action of polyphenol oxidase leads to major economic losses in some fresh fruits and vegetables (Osuga et al., 1994). Browning also leads to off-flavors and losses in nutritional quality. Browning reactions in mushroom are caused by tissue breakdown due to senescence, mechanical damage or bacterial activity (Burton, 1986, and Vizhanyo \& Felföldi, 2000). Hence, the product acceptability and consumer's preference are reduced. Therefore, monitoring the changes in mushrooms composition, colour, texture and microbial activity and reducing their degradation are very important. Moreover, find simple, cheap and safe treatment to control the fast quality deterioration provides ample opportunity for the mushroom growers and marketers to reduce the economic losses.

Hydrogen peroxide is a simple, short-lived and highly reactive molecule that performs multiple functions in early defense responses against pathogens and the hypersensitive response ( $\mathrm{Hu}$ et al., 2003). $\mathrm{H}_{2} \mathrm{O}_{2}$ accumulates during normal metabolism (photosynthesis, respiration, growth, senescence and stomatal close) and various abiotic and biotic stress conditions, including low and high temperature, salt stress and pathogenic stress (Urszula and Rozalska, 2005). $\mathrm{H}_{2} \mathrm{O}_{2}$ is strong oxidizer proposed as an alternative means of decontaminating fruits and vegetables. It has been effective on extending the shelf life of cantaloupe, cucumber, zucchini, bell peppers, grapes, and mushrooms (Forney et al., 1991 and Sapers\&Simmons, 1998). An important characteristic of this molecule is that it rapidly degrades into oxygen and water upon contacting organic material, thus having no long term residual activity. Hence, hydrogen peroxide is classified as Generally Regarded As Safe (GRAS) for use in foods (FDA, 1998). It is generally use as a bleaching and antimicrobial agent and could control the bacterial blotch and browning of mushrooms (Raffellini et al., 2008). Moreover, washing in $\mathrm{H}_{2} \mathrm{O}_{2}$ solution can markedly reduce human pathogens E. coli and Salmonella spp. (Ukuku et al., 2005).

Egypt. J. Hort. Vol. 43, No.1 (2016) 
In this study, attempts were made to use different concentrations of hydrogen peroxide as dipping treatment after harvest to control the fast loss in mushroom quality. Besides the changes in composition, texture and colour characteristics as well, the monitoring of microbial activity and sensory evaluation during postharvest period were studied.

\section{Materials and Methods}

This study was carried out at the laboratory of Department of Vegetable and Mushroom Growing, Faculty of Horticulture, Corvinus University, Budapest, Hungary during the period of April to July 2014. Closed cap button mushrooms (Agaricusbisporus) were delivered to the laboratory and selected for white, uniform, clear, and fresh. Fruit bodies were divided into four groups with the same size and shape. Every group contained eighty fruit bodies, put in suitable container and prepared for the treatments.

\section{Treatments}

Three concentrations from hydrogen peroxide (1,2 and 4\%) were used beside the control (distilled water only)as all were dipped for 15 minutes. After drying, the mushrooms were packed at high-density polyethylene bags then stored at $4 \pm$ $1^{\circ} \mathrm{C}$ and $90 \pm 2 \% \mathrm{RH}$ for 10 days. The samples were taken at random before storing and after 5 and ten days. The experiment was repeated twice and the results were the average of the two experiments.

\section{Measurements \\ Colour measurements}

The colour of the mushroom cap was measured using a Minolta Chroma Meter (Model CR-155, Minolta Camera Co., Osaka, Japan), using the Hunter Lab Colour Scale. Four mushrooms were randomly selected from each sample and the colour was measured at four equidistant points on each mushroom cap using an aperture diameter of $4 \mathrm{~mm}$. Mushroom colour has been commonly measured using the $\mathrm{L}^{*}$ value of the Hunter scale (Cliffe-Byrnes and O'Beirne, 2007), however some studies have pointed to changes in other parameters of the hunter scale $\left(\mathrm{a}^{*}\right.$ and $\mathrm{b}^{*}$ ) related to browning (Vizhanyo \& Felföldi, 2000and Aguirre et al., 2008). In order to capture this variation in a single index that would be related to a turn towards brown colour, browning index (BI) was calculated according to Bozkurt \& Bayram (2006) and Ruangchakpet \& Sajjaanantakul (2007) using the following equation:

Browning Index $(\mathrm{BI})=[100(\mathrm{x}-0.31)] / 0.17$, where $\mathrm{x}=\left(\mathrm{a}^{*}+1.75 \mathrm{~L}^{*}\right) /$ $\left(5.645 \mathrm{~L}^{*}+\mathrm{a}^{*}-0.3012 \mathrm{~b}^{*}\right), \mathrm{L}^{*}$ value indicates lightness of the colour, which range from 0 (dark) to 100 (white). The positive value of $\mathrm{a}^{*}$ indicates red colour, while negative value indicates green colour. The positive value of $b^{*}$ indicates yellow colour, while negative value indicates blue colour.

\section{Chemical constituents}

Dry matter\%:5g of fruiting bodies were weighed in a Petri dish and placed in an electric oven at $70^{\circ} \mathrm{C}$ for $72 \mathrm{hrs}$ until a constant weight was attained. Moisture 
content was calculated using the formula, moisture content $(\%)=($ Fresh weight Dry weight $) /$ Fresh weight $\times 100$. The dry matter content was calculated since, dry matter $(\%)=(100-$ moisture content $\%)$.

Total soluble solids (TSS\%, Brix): They were determined in juice squeezed from undamaged pieces of tissue cut from the mushrooms for each treatment by digital hand-hold refractometer (HI9680, HANNA, Europe).

Protein\%: It was calculated by multiplying nitrogen content by 4.7. Nitrogen content was estimated using the modified micro-Kjeldahl method (A.O.A.C., 1990). This is expressed as crude protein since the non-protein nitrogen was also taken into consideration in the present method of protein determination.

pH: It was measured with a digital pH meter (Mettler Toledo, model MP 220, Schwerzenbach, Switzerland).

\section{Cell membrane permeability}

It was expressed by relative electrolyte leakage percentage according to the described procedures byKaya et al. (2002). In order to remove the surface contamination, mushroom discs ( $3 \mathrm{~mm}$ thick, $3 \mathrm{~mm}$ diameter) $5 \mathrm{~g}$ total were immersed in $50 \mathrm{ml}$ distilled water for $1 \mathrm{~h}$, then the mushroom discs were taken out and immersed in another $50 \mathrm{ml}$ distilled water and incubated at ambient temperature $\left(20 \pm 3{ }^{\circ} \mathrm{C}\right)$. Conductivity of the suspending solution was measured at $3 \mathrm{~h}$ and after boiling for $30 \mathrm{~min}$ with an electrical conductivity meter (HI 98312, HANNA, Woonsocket, RI, USA). Relative electrolyte leakage (\%) was calculated as the ratio of the electrolyte leakage after $3 \mathrm{~h}$ of submersion to the total value.

\section{Physical measurements}

Firmness (Kgf): it was evaluated on the mushroom cap using a texture analyzer (TA-XT2i, Stable Micro Systems Ltd., Godalming, UK) with a $2 \mathrm{~mm}$ diameter cylindrical probe according to the described method byJiang et al. (2010). Samples were penetrated to a depth of $10 \mathrm{~mm}$. The speed of the probe was $5.0 \mathrm{~mm} \mathrm{~s}^{-1}$ during the pre-test and penetration. Measurements were performed in triplicate on four mushroom caps for each sample and the mean was calculated.

\section{Weight loss\%}

It was measured every 3 days during cooling storage. Weight loss $\%=100^{*}$ (weight before storage - weight after storage)/ (weight before storage).

\section{Microbial activities}

It was performed according to FDA Standard Methods (FDA, 1998). Appropriate serial dilutions were prepared in sterile $0.1 \%$ Bacto-Peptone plated in duplicate. Total plate counts (TPC) were performed using plate count agar. Yeasts and moulds were enumerated using potato dextrose agar acidified to a final $\mathrm{pH}$ of 3.5 with tartaric acid.

Egypt. J. Hort. Vol. 43, No.1 (2016) 
Sensory quality

A panel of ten trained judges evaluated the sensory quality characteristics of the mushrooms from each tray. The typical characteristics of the mushrooms and the possibilities of deterioration were explained before the experiment start. All sensory tests (general appearance, firmness and colour) were performed. These characters were evaluated on a scale of 9-1 where: $9=$ excellent, $7=$ good, $5=$ fair, $3=$ poor, $1=$ extremely poor (Ding and Ling, 2014).

\section{Statistical analysis}

Completely randomized design in three replicates was used. Data were analyzed by one-way analysis of variance using statistical software SPSS 18.0 for windows. Significant differences in mean values were evaluated by Tukey test at $(p<0.05)$ in accordance with Sokal and Rohlf $(1995)$.

\section{Mushroom colour}

\section{Results}

The changes in mushroom fruits colour are shown in Table 1. There was a clear discolouration with progress storage time. The increase in positive values of $\mathrm{a}^{*}$ and $\mathrm{b}^{*}$ pointed out the degradation in the colour towards redness and yellowish at the expense of the white colour. The reduction in white colour was expressed by decreasing $\mathrm{L}^{*}$ value from 97.90 to 80.77 after 10 days storage. The reduction in $\mathrm{L}^{*}$ and the increase in $\mathrm{a}^{*}$ and $\mathrm{b}^{*}$ reflected to an increase in browning index from 7.92 to 33.04 .

Hydrogen peroxide treatment kept the white colour and reduced discolouration of mushrooms comparing to the control (immersing in distilled water) at both storage periods (5 and 10 days). It was noticed that 2 or $4 \% \mathrm{H}_{2} \mathrm{O}_{2}$ (without significant differences in between) had lower a* by $48 \%$, b* by $32 \%$ and browning index by $45 \%$ than the control, while $\mathrm{L}^{*}$ was increased by $114 \%$. These findings indicated that immersing mushrooms in $2 \%$ of $\mathrm{H}_{2} \mathrm{O}_{2}$ before storage decreased mushrooms discolouration and retained the white colour.

\section{Chemical constituents}

Data concerning changes in mushroom composition during storage are presented in Table 2. A slight increase in dry matter percentage as storage time advanced was occurred in control samples. Increasing $\mathrm{H}_{2} \mathrm{O}_{2}$ concentration enhanced significantly DM\% at both storage periods. The highest concentration of $\mathrm{H}_{2} \mathrm{O}_{2}(4 \%)$ duplicated DM\% which increased from 6.1 to $15.5 \%$ after 10 days of storage.

Mushrooms content of total soluble solids and protein tended to decrease during storage. Immersing mushrooms before storage in $\mathrm{H}_{2} \mathrm{O}_{2}$ compared to in water caused a significant reduction in TSS\% after 5 days storage, then the contrast was occurred after 10 days storage. At the end of storage, the highest concentrations of $\mathrm{H}_{2} \mathrm{O}_{2}$ (2 or $4 \%$ ) decreased $\mathrm{TSS} \%$ by $17 \%$ compared with that before storage, while the reduction reached to $53 \%$ in the control. 
TABLE 1. Colour changes during storage of treated Agaricus mushrooms by $\mathrm{H}_{2} \mathrm{O}_{2}$ concentrations.

\begin{tabular}{|c|c|c|c|c|}
\hline \multirow{4}{*}{$\mathbf{H}_{\mathbf{2}} \mathbf{O}_{2}$ conc. } & $\mathbf{a}^{*}$ & $\mathbf{b}^{*}$ & $\mathbf{L}^{*}$ & BI \\
\cline { 2 - 5 } & \multicolumn{4}{|c|}{ Zero time (before storage) } \\
\cline { 2 - 5 } & $\mathbf{0 . 5 8}$ & $\mathbf{7 . 2 3}$ & $\mathbf{9 7 . 9 0}$ & $\mathbf{7 . 9 2}$ \\
\cline { 2 - 5 } & \multicolumn{4}{|c|}{ After 5 days storage } \\
\hline \multirow{3}{*}{$\begin{array}{c}0 \% \text { (cont.) } \\
1 \% \\
2 \% \\
4 \%\end{array}$} & $3.24 \pm 0.20^{\mathrm{a}}$ & $18.20 \pm 0.91^{\mathrm{a}}$ & $87.60 \pm 0.62^{\mathrm{c}}$ & $25.58 \pm 1.50^{\mathrm{a}}$ \\
\cline { 2 - 5 } & $2.05 \pm 0.31^{\mathrm{b}}$ & $13.16 \pm 0.99^{\mathrm{b}}$ & $88.35 \pm 0.36^{\mathrm{c}}$ & $17.51 \pm 1.26^{\mathrm{b}}$ \\
\cline { 2 - 5 } & $1.19 \pm 0.18^{\mathrm{c}}$ & $11.02 \pm 0.39^{\mathrm{c}}$ & $94.26 \pm 0.51^{\mathrm{a}}$ & $13.07 \pm 0.50^{\mathrm{c}}$ \\
\cline { 2 - 5 } & $0.95 \pm 0.18^{\mathrm{c}}$ & $11.26 \pm 0.21^{\mathrm{c}}$ & $92.49 \pm 0.53^{\mathrm{b}}$ & $13.43 \pm 0.21^{\mathrm{c}}$ \\
\hline \multirow{3}{*}{$\begin{array}{c}\text { 0\% (cont.) } \\
1 \%\end{array}$} & $3.74 \pm 0.20^{\mathrm{a}}$ & $21.08 \pm 0.96^{\mathrm{a}}$ & $80.77 \pm 0.17^{\mathrm{c}}$ & $33.04 \pm 1.33^{\mathrm{a}}$ \\
\cline { 2 - 5 } $\begin{array}{c}2 \% \\
4 \%\end{array}$ & $2.65 \pm 0.11^{\mathrm{b}}$ & $17.90 \pm 0.53^{\mathrm{b}}$ & $85.50 \pm 0.77^{\mathrm{b}}$ & $25.31 \pm 0.87^{\mathrm{b}}$ \\
\cline { 2 - 5 } & $1.94 \pm 0.08^{\mathrm{c}}$ & $14.24 \pm 0.47^{\mathrm{c}}$ & $92.54 \pm 0.67^{\mathrm{a}}$ & $17.90 \pm 0.65^{\mathrm{c}}$ \\
\cline { 2 - 5 } & $1.95 \pm 0.03^{\mathrm{c}}$ & $14.37 \pm 0.48^{\mathrm{c}}$ & $91.17 \pm 0.44^{\mathrm{a}}$ & $18.37 \pm 0.64^{\mathrm{c}}$ \\
\hline
\end{tabular}

Different letters in the same column indicate that means are significantly different $(\mathrm{P}<0.05)$. $\mathrm{a}^{*}, \mathrm{~b}^{*}$ and $\mathrm{L}^{*}$ indicate red, yellow and white colours, respectively. $\mathrm{BI}=$ browning index.

TABLE 2. Composition changes during storage of treated Agaricus mushrooms by $\mathrm{H}_{2} \mathrm{O}_{2}$ concentrations.

\begin{tabular}{|c|c|c|c|c|c|}
\hline \multirow{3}{*}{$\begin{array}{l}\mathrm{H}_{2} \mathrm{O}_{2} \\
\text { conc. }\end{array}$} & DM\% & TSS\% & Protein & pH & MP \\
\hline & \multicolumn{5}{|c|}{ Zero time (before storage) } \\
\hline & 6.09 & 4.92 & 29.88 & 6.216 & 6.70 \\
\hline \multicolumn{6}{|c|}{ After 5 days storage } \\
\hline \multirow{4}{*}{$\begin{array}{c}0 \% \\
\text { (cont.) } \\
1 \% \\
2 \% \\
4 \%\end{array}$} & $6.40 \pm 0.15^{\mathrm{d}}$ & $3.87 \pm 0.09^{\mathrm{a}}$ & $27.60 \pm 0.28^{c}$ & $6.240 \pm 0.006^{\mathrm{b}}$ & $27.97 \pm 1.08^{\mathrm{a}}$ \\
\hline & $7.38 \pm 0.20^{c}$ & $1.77 \pm 0.30^{c}$ & $28.50 \pm 0.19^{b}$ & $6.264 \pm 0.049^{b}$ & $22.63 \pm 0.38^{b}$ \\
\hline & $8.8 \pm 0.28^{b}$ & $2.87 \pm 0.26^{\mathrm{b}}$ & $29.48 \pm 0.10^{\mathrm{a}}$ & $6.376 \pm 0.068^{\mathrm{a}}$ & $20.63 \pm 0.18^{\mathrm{c}}$ \\
\hline & $9.47 \pm 0.32^{\mathrm{a}}$ & $2.83 \pm 0.12^{b}$ & $29.13 \pm 0.13^{\mathrm{a}}$ & $6.382 \pm 0.005^{\mathrm{a}}$ & $21.53 \pm 0.14^{\mathrm{bc}}$ \\
\hline \multicolumn{6}{|c|}{ After 10 days storage } \\
\hline \multirow{4}{*}{$\begin{array}{c}0 \% \\
\text { (cont.) } \\
1 \% \\
2 \% \\
4 \%\end{array}$} & $7.98 \pm 0.28^{\mathrm{b}}$ & $2.31 \pm 0.06^{\mathrm{b}}$ & $25.21 \pm 0.55^{\mathrm{c}}$ & $6.076 \pm 0.021^{\mathrm{b}}$ & $36.50 \pm 0.47^{\mathrm{a}}$ \\
\hline & $9.42 \pm 0.56^{\mathrm{b}}$ & $2.80 \pm 0.40^{\mathrm{b}}$ & $26.04 \pm 0.55^{\mathrm{bc}}$ & $6.086 \pm 0.038^{b}$ & $32.57 \pm 0.41^{\mathrm{b}}$ \\
\hline & $13.59 \pm 1.43^{\mathrm{a}}$ & $4.12 \pm 0.46^{\mathrm{a}}$ & $28.29 \pm 0.23^{\mathrm{a}}$ & $6.338 \pm 0.014^{\mathrm{a}}$ & $27.73 \pm 0.35^{\mathrm{d}}$ \\
\hline & $15.54 \pm 0.91^{\mathrm{a}}$ & $4.10 \pm 0.21^{\mathrm{a}}$ & $27.33 \pm 0.11^{\mathrm{ab}}$ & $6.392 \pm 0.045^{\mathrm{a}}$ & $29.70 \pm 0.26^{c}$ \\
\hline
\end{tabular}

Different letters in the same column indicate that means are significantly different $(\mathrm{P}<0.05)$. DM=dry matter, $\mathrm{TSS}=$ total soluble solids, $\mathrm{MP}=$ Membrane permeability.

Egypt. J. Hort. Vol. 43, No.1 (2016) 
$\mathrm{H}_{2} \mathrm{O}_{2}$ was effective to reduce protein loss during storage comparing to the control. The concentration of either 2 or $4 \% \mathrm{H}_{2} \mathrm{O}_{2}$ (without significant differences in between) reduced the degradation in protein content $9 \%$ over the control by the end of storage period. Protein content in control samples was reduced up to $16 \%$ compared to that before storage, however it reached only $7 \%$ reduction with high $\mathrm{H}_{2} \mathrm{O}_{2}$ concentrations ( 2 or $4 \%$ ).

Mushrooms $\mathrm{pH}$ increased in all stored mushrooms after 5 days storage, and then was reduced. An exception with $4 \% \mathrm{H}_{2} \mathrm{O}_{2}$ treatment was obtained which $\mathrm{pH}$ continued to increase until the end of storage period. The highest $\mathrm{pH}$ (6.392) was registered with $4 \% \mathrm{H}_{2} \mathrm{O}_{2}$ treatment after 10 days of storage.

\section{Cell membrane permeability}

Regardless treatments, the relative cell membrane permeability expressed by ions leakage of mushrooms increased steadily with increasing storage time. $\mathrm{H}_{2} \mathrm{O}_{2}$ treatments especially with $2 \%$ concentration declined significantly membrane permeability compared to the control during both storage periods.

\section{Physical measurements}

According to the physical measurements, the caps of mushroom gradually became less firm as storage time progressed (Fig. 1). Hydrogen peroxide treatment decreased the degradation in firmness compared to the control. The higher concentrations ( 2 and $4 \% \mathrm{H}_{2} \mathrm{O}_{2}$ ) were effective for keeping more hardness in mushroom caps than the lower concentrations $\left(0\right.$ and $\left.1 \% \mathrm{H}_{2} \mathrm{O}_{2}\right)$. After 10 days storage, the firmness was $3.7 \mathrm{kgf}$ with $2 \% \quad \mathrm{H}_{2} \mathrm{O}_{2}$ treatment, however it was $2.4 \mathrm{kgf}$ in the control.

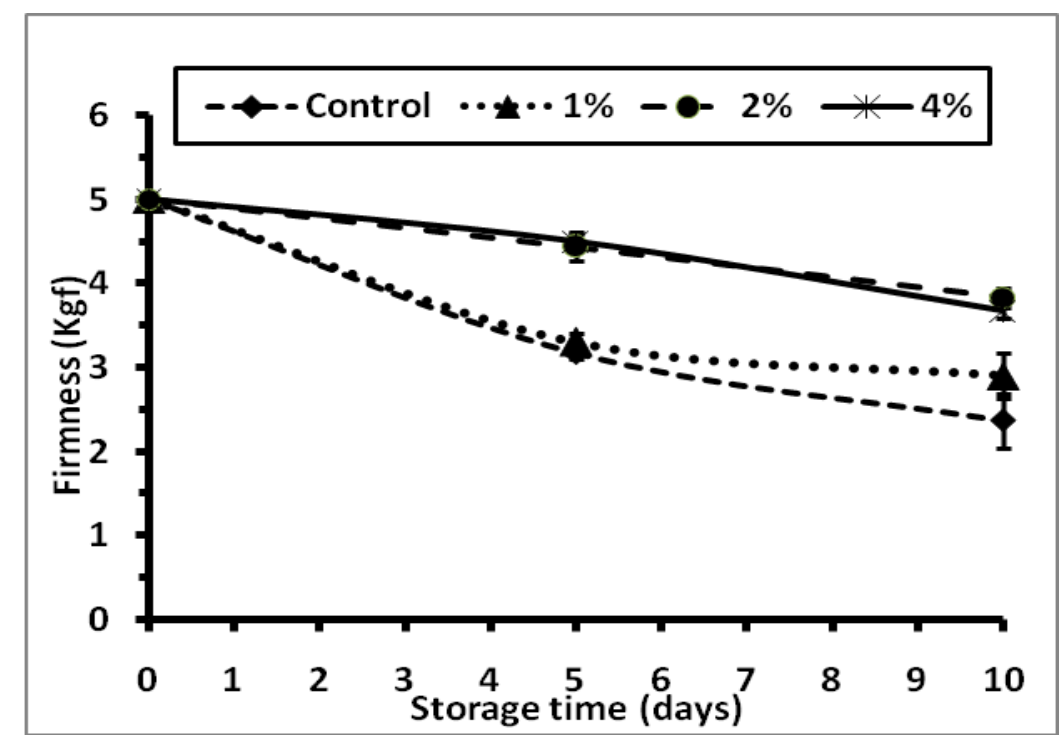

Fig. 1. Changes in firmness during storage of treated Agaricus mushrooms by $\mathrm{H}_{2} \mathrm{O}_{2}$ concentrations. 


\section{Weight loss}

A gradual increase in mushrooms weight loss with progress storage time was evident in Fig. 2. However, the differences were increased between the control and the $\mathrm{H}_{2} \mathrm{O}_{2}$ treatments at early storage periods, but they were decreased among $\mathrm{H}_{2} \mathrm{O}_{2}$ concentrations. The differences increased with increasing storage time, while the high $\mathrm{H}_{2} \mathrm{O}_{2}$ concentrations achieved the lowest weight loss without significant differences in between. Mushrooms lost $7.5 \%$ of their weight after 3 days storage in the control and reached $25 \%$ after 10 days, whereas it was $4.9 \%$ with $4 \% \mathrm{H}_{2} \mathrm{O}_{2}$ treatment and reached to $10 \%$ by the end of storage time with $15 \%$ lower than the control.

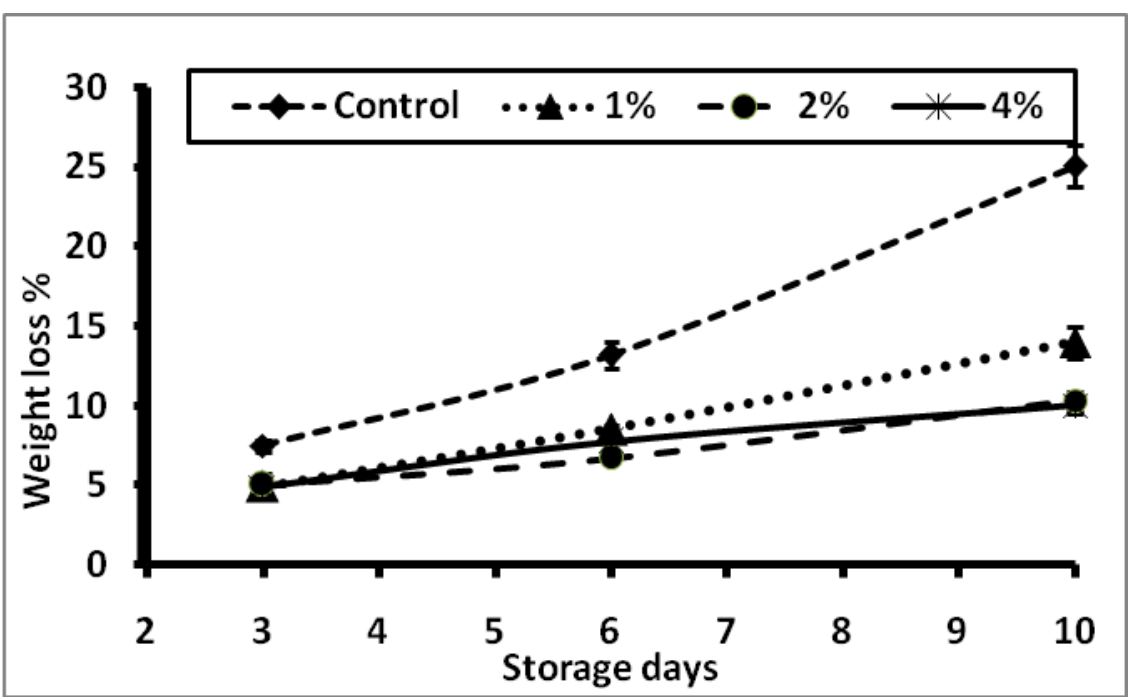

Fig. 2. Weight loss during storage of treated Agaricus mushrooms by $\mathrm{H}_{2} \mathrm{O}_{2}$ concentrations

\section{Microbial activities}

Mushroom's surface content of yeasts and molds increased steadily in the control with increasing storage time (Fig. 3). It was 5.2 CFU/g mushroom at the beginning and reached 7.7 CFU at the end of storage period. Hydrogen peroxide treatments delayed the development of yeasts and molds count. The count decreased from 6.2 to $4.3 \mathrm{CFU} / \mathrm{g}$ after 5 days storage and from 7.7 to $5.9 \mathrm{CFU} / \mathrm{g}$ with $2 \% \mathrm{H}_{2} \mathrm{O}_{2}$ treatment compared to the control after 10 days storage. Hence, it was the most effective treatment to control the yeasts and molds. Although $\mathrm{H}_{2} \mathrm{O}_{2}$ treatments markedly inhibited yeasts and molds compared to the control, the differences among the concentrations were insignificant after 5 days storage. At the end of storage period, the differences appeared significantly. Meanwhile, the highest concentrations ( 2 or $4 \% \mathrm{H}_{2} \mathrm{O}_{2}$ ) had the strongest inhibition on yeasts and molds count with insignificant differences in between. 


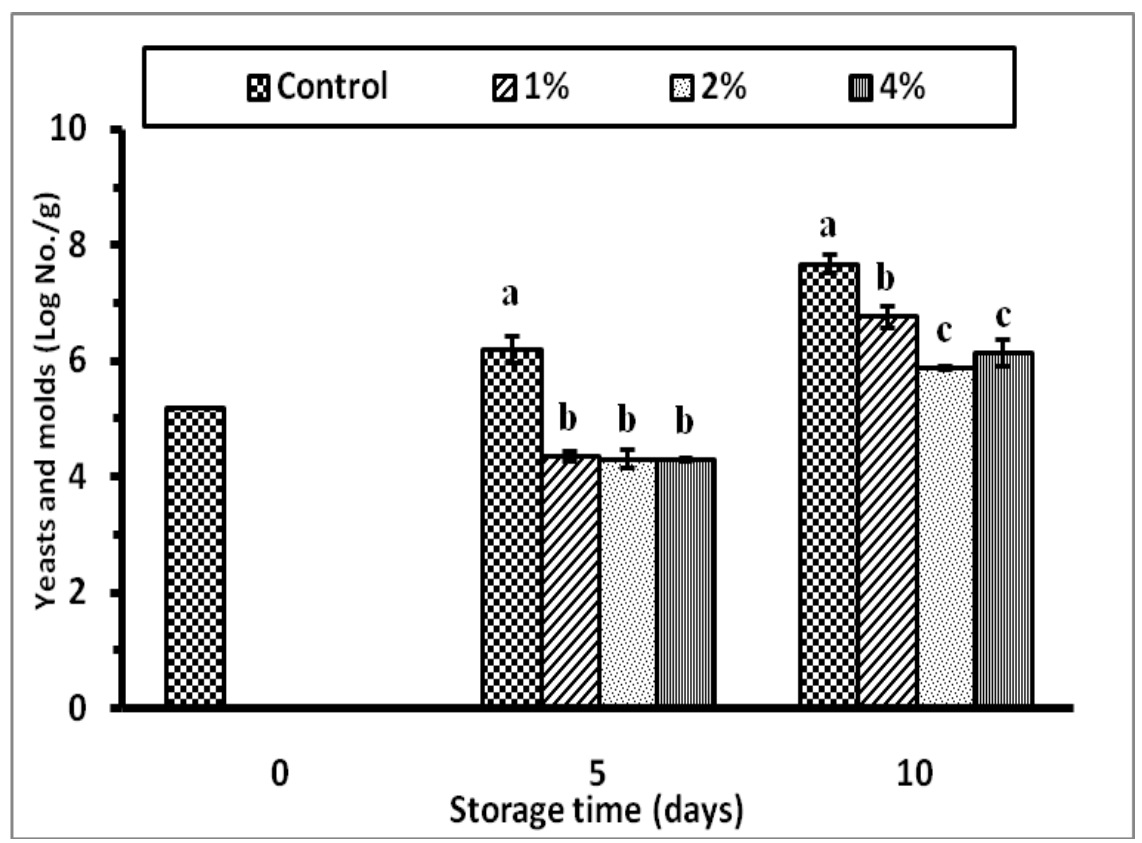

Fig. 3. Changes in yeasts and molds content during storage of treated Agaricus mushrooms by $\mathrm{H}_{2} \mathrm{O}_{2}$ concentrations (Different letters above bars in the same period indicate significant differences between means)

Mushrooms content of total bacterial count is shown in Fig. 4. Total bacterial count increased gradually during storage at all studied samples with the highest values in the control samples. At both storage periods, $2 \% \mathrm{H}_{2} \mathrm{O}_{2}$ had the most inhibition effect without significant differences with the other concentrations after 5 days storage. At the end of storage time, $2 \%$ and $4 \%$ concentrations did not statistically differ. With $2 \% \mathrm{H}_{2} \mathrm{O}_{2}$ treatment, total bacterial count decreased from 8.0 to $5.8 \mathrm{CFU} / \mathrm{g}$ after 5 days storage and from 10.0 to $7.9 \mathrm{CFU} / \mathrm{g}$ compared to the control, at the end of storage period. However, $1 \% \mathrm{H}_{2} \mathrm{O}_{2}$ did not significantly differ than the control at the end of storage period.

\section{Sensory evaluation}

Finally, the samples were evaluated sensory for texture, colour and overall acceptance and the results were illustrated in Fig. 5 for all appearance parameters, the control tended to be the lowest. It scored 2.7, 3.7 and 6.5 of colour, texture and overall acceptance scores respectively. For the same parameters, $2 \% \mathrm{H}_{2} \mathrm{O}_{2}$ had favorable sensory evaluation with scores of 8.5, 8.2 and 8.5 , respectively, although the differences were insignificant between 2 and $4 \% \mathrm{H}_{2} \mathrm{O}_{2}$. 


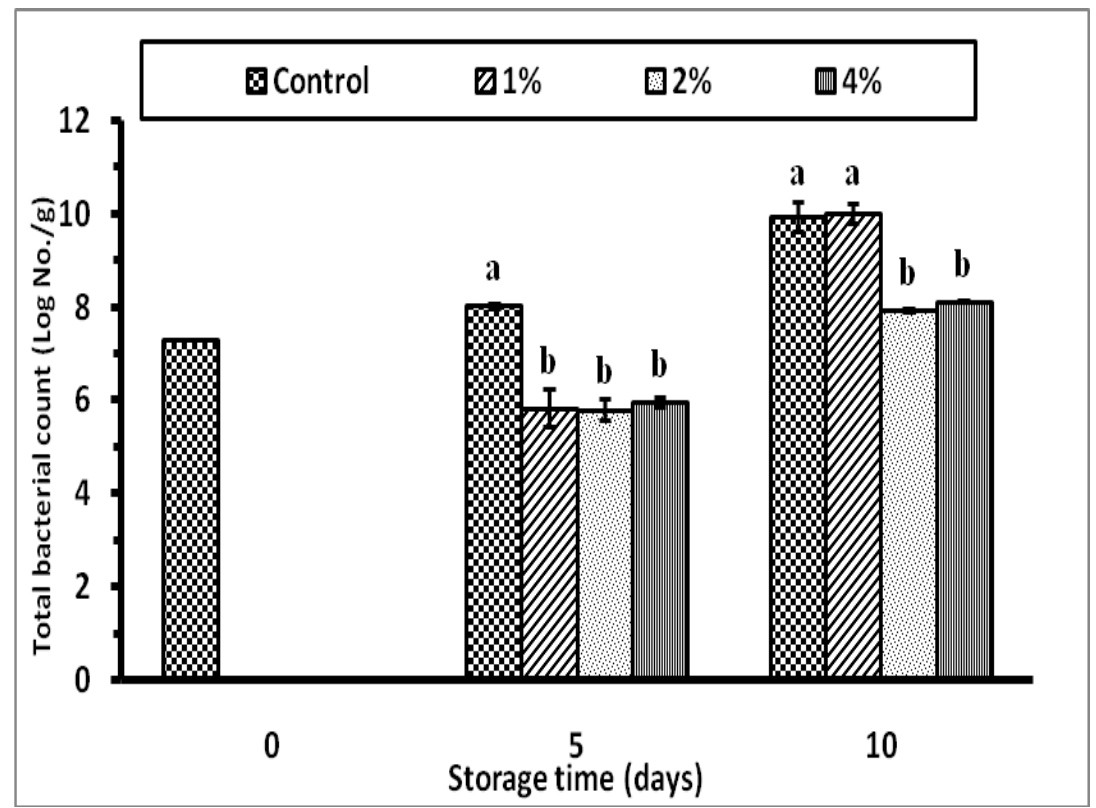

Fig. 4. Changes in total count bacteria content during storage of treated Agaricus mushrooms by $\mathrm{H}_{2} \mathrm{O}_{2}$ concentrations (Different letters above bars in the same period indicate significant differences between means).

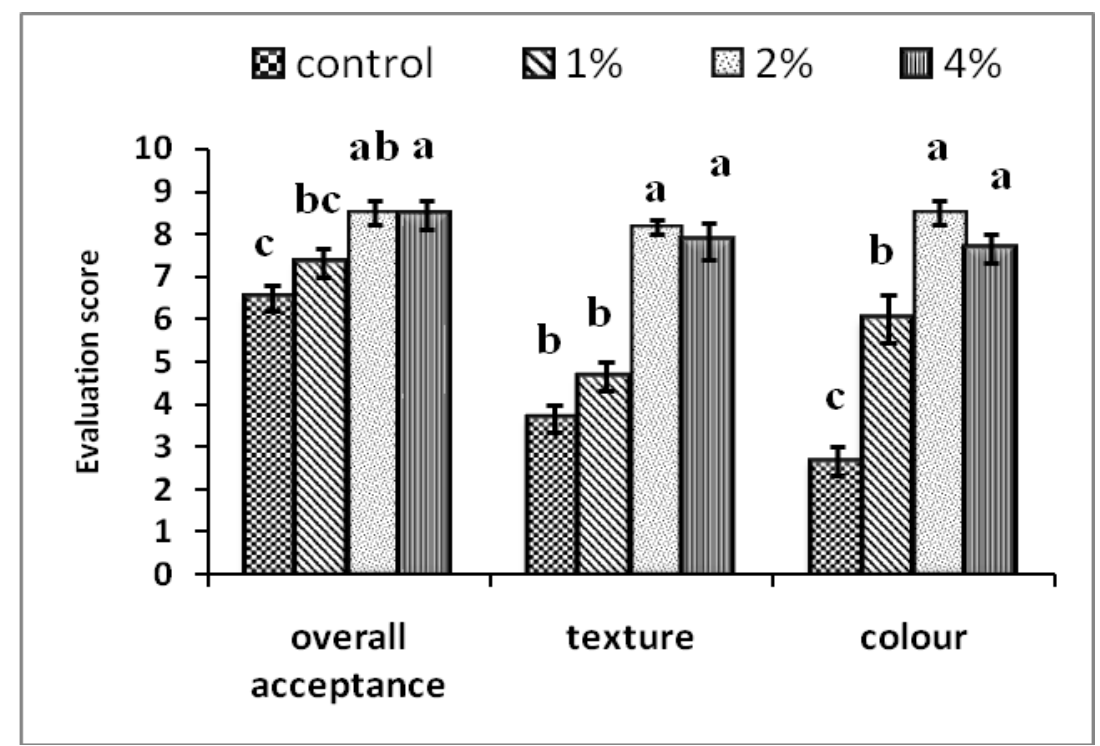

Fig. 5. Sensory evaluation of treated Agaricus mushrooms by $\mathrm{H}_{2} \mathrm{O}_{2}$ concentrations, after 10 days storage (Different letters above bars in the same period indicate significant differences between means).

Egypt. J. Hort. Vol. 43, No.1 (2016) 


\section{Discussion}

In this study, the received mushrooms were predominantly white but as storage time progressed discolouration in fruit bodies was occurred. Browning index as well as white colour measurement are good indicators for discolouration. Browning index formula considered the changes in $\mathrm{a}^{*}$ (red and green colour), $\mathrm{b}^{*}$ (yellow and blue colour) and $\mathrm{L}^{*}$ (white colour) which was more suitable for colour changes measurements. Two mechanisms could be drawn to explain browning process: a) non-enzymatic reactions (Jolivet et al., 1998) and b) enzymatic reactions mainly by polyphenol oxidases enzymes family (Mohapatra et al., 2008 and Ding \& Ling, 2014) spontaneous in the fruits or via microorganism's activities (Raffellini et al., 2008). Non-enzymatic browning is due to (i) Maillard reaction involving interaction between reducing sugars, amino acids and proteins (ii) reaction of oxidation products of ascorbic acid with proteins or amino acids (iii) reaction of oxidation products of polyunsaturated fatty acids with amino acids and proteins and (iv) caramelisation of sugars. Mushrooms do contain sugars, amino acids and proteins, hence non-enzymatic browning is possible (Swaminathan, 1988). During handling, storage and aging of mushrooms, the membranes separating the partitions are ruptured and breakdown the contents mix, the enzyme becomes activated and the browning reaction begins (Burton, 1986). Phenylalanine ammonia lyase, polyphenol oxidase and peroxidase are generally active during browning development (Peng et al., 2008). The relationship between browning and microbial activity was also reported by Wells et al. (1996). From the previous illustrations, hydrogen peroxide could be interacted with these explanations. It was reported that hydrogen peroxide reduced non-enzymatic browning (Nerya et al., 2005), enzymatic browning (Peng et al., 2008) and microbial activity (Crowe et al., 2005 and Raffellini et al., 2008). The presented results in Table 1 and the illustration in Fig 6 support these findings. They indicated that immersing mushrooms after harvest in $\mathrm{H}_{2} \mathrm{O}_{2}$ reduced significantly discolouration during storage, especially with $2 \%$ concentration.

The short postharvest period of mushrooms due to: the very high respiration rate which is being three times greater than most fruits (Farber et al., 2003), very high water content which it ranged between 85 and 95\% (Table 2), thin and weak cell walls and lack cuticles to protect them from physical damage, microbial attack and water loss (Martin \& Maris, 2012 andLagnikaet al., 2014), and the fast degradation in cells composition (Hammond \& Nicolas, 1975 and Rai \& Saxena, 1989, Table 2). The reduction in TSS could be attributed to the consumption of sugars (the main component of soluble solids) during respiration processes (Hammond and Nicolas, 1975). During the procedure of respiration, carbohydrates are broken down to their constituents to produce energy to run cellular processes, thus keeping the cells and organism alive. During this process, oxygen is consumed and water, carbon dioxide and energy are released. The carbohydrates stored in the harvested mushroom are continually 'burned' as energy source to keep it alive. As respiration continues, compounds that affect 
flavour, sweetness, weight, turgor (water content), and nutritional value decrease gradually (Lagnikaet al., 2014). The activity of protease enzyme activity resulted in a reduction in protein content of storage mushrooms with a temporary accumulation of free amino acids (Rai and Saxena, 1989) then decrease after that with a reduction in cell wall glucan(Hammond, 1979). The degradation in cell wall components leads to that the membrane systems became more vulnerable to leakage. The presented results in Table 2 showed a reduction in membrane permeability with storage time progress. In this concern, Saltveit (2002) reported that changing membrane structure caused an increase in permeability and ion leakage. Tao et al. (2006) and Li et al. (2008) results supported these findings in stored Agaricus mushrooms. The degradation in composition during storage included reduction in total soluble solids and protein content with an increase in membrane permeability (Table 2). This degradation reflected on a decrease in hardness (Fig. 1) and increases in weight loss (Fig. 2) as well as the tissues were sensitive to attack by microorganisms (Fig. $3 \& 4$ ) by the end of storage time.

$\mathrm{H}_{2} \mathrm{O}_{2}$ accumulates during normal metabolism and abiotic and biotic stress conditions (Urszula and Rozalska, 2005). However, excess $\mathrm{H}_{2} \mathrm{O}_{2}$ can induce oxidative stress, injuring the cells. When the amount of $\mathrm{H}_{2} \mathrm{O}_{2}$ accumulation is conserved at normal level by a series of antioxidant molecular and enzymes, $\mathrm{H}_{2} \mathrm{O}_{2}$ acts as a second messenger and functions with other important signal molecules (Neill et al., 2002). They act together to protect tissues from stresses and in regulating growth and development. $\mathrm{H}_{2} \mathrm{O}_{2}$ production is essential during growth, development and resistance responses (Van Breusegem et al., 2001). As a stable ROS (reactive oxygen species), $\mathrm{H}_{2} \mathrm{O}_{2}$ has great ability to buffer other ROS molecules. In another view, the balance between $\mathrm{H}_{2} \mathrm{O}_{2}$ and cell redox under oxygen scavenging enzymes plays a versatile role in changing oxygen relative effect on cells and altering cell resistance mechanism (Quan et al., 2008). Peng et al. (2008) reported that $\mathrm{H}_{2} \mathrm{O}_{2}$ effectively inhibited the activity of phenolic related metabolic enzymes (polyphenol oxidase and peroxidase) and delayed surface discolouration. It maintained eating quality together with taste (total soluble solids and acidity) and nutritional attributes (ascorbic acid). In the same line but with high concentration, Das et al. (2010) found that washing mushrooms in 5\% hydrogen peroxide reduced quality loss including freshness, colour, weight loss and disease incident during the storage which also increased protein and dry matter content compared to unwashed control. $\mathrm{H}_{2} \mathrm{O}_{2}$ also performs multiple functions in early defence response against pathogens $(\mathrm{Hu}$ et al., 2003) andsuppressed microorganism's activity (Crowe et al., 2005 and Raffellini et al., 2008, Fig. 3 \& 4). The antimicrobial action stems from its ability to form reactive oxygen species such as the hydroxyl radical and singlet oxygen, which can damage bacterial protein, DNA and cellular membrane components (Juven and Pierson, 1996), and remove protein coats of bacterial spores. However, its action is affected by organic load but not by $\mathrm{pH}$ (Walker \& Marsh, 2007 and Martin \& Maris 2012) which may be the reason of the variation among the previous findings in the effective concentration. The role of $\mathrm{H}_{2} \mathrm{O}_{2}$ in maintaining eating quality appeared in Table 2 which kept high dry matter, total

Egypt. J. Hort. Vol. 43, No.1 (2016) 
soluble solids and acidity with high nutritional value (protein content). When the good colour (Table 1) and hardness (Fig. 1) added to the high eating quality with $\mathrm{H}_{2} \mathrm{O}_{2}$ treatment, these positively reflected on score of overall acceptance in the sensory evaluation (Fig. $5 \& 6$ ).

\section{Conclusion}

- Immersing white button mushroom in hydrogen peroxide after harvesting as a simple, cheap, short-lived and safe treatment was effective to decrease significantly the deterioration during cold storage.

- Hydrogen peroxide with the concentration of $2 \%$ was the most efficient for keeping quality during 10 days cold storage.

- $\quad 2 \%$ hydrogen peroxide treatment maintained a good white colour and reduced the browning of fresh mushroom fruits bodies.

- $\quad 2 \%$ hydrogen peroxide decreased significantly weight loss, membrane permeability, total bacterial count, yeasts and molds during 10 days cold storage.

- Good consuming quality (total soluble solids, acidity, dry matter and hardness), nutritional value (protein content), microbial safety (low molds, fungi and total bacterial count) and sensory attributes were obtained with $2 \%$ hydrogen peroxide treatment.

Acknowledgements: Sincere thanks are due to Dr Seham Swelam, Kafrelsheikh Univ., Egypt for her help and support to complete this work. I also wish to express my great thanks to Dr Peregi Katalin for her support and host the project at department of vegetable and mushroom growing, Faculty of Horticultural Science, Corvinus University of Budapest.

\section{References}

Aguirre, L., Frías, J.M., Barry-Ryan, C. and Grogan, H. (2008) Assessing the effect of product variability on the management of the quality of mushrooms (Agaricusbisporus). Postharvest Biol. Technol., 49, 247-254.

A.O.A.C. (1990) "Official Methods of Analysis", $15^{\text {th }}$ ed.,Association of Official Analytical Chemists, Washington D.C.

Bozkurt, H. and Bayram, M. (2006) Color and textural attributes of sucuk during ripening. Meat Sci.,73 (2), 344-50.

Burton, K.S. (1986) Quality investigations into mushroom browning. Mushroom Journal,158, 68-70.

Cliffe-Byrnes, V. and O'Beirne, D. (2007) Effects of gas atmosphere and temperature on the respiration rates of whole and sliced mushrooms (Agaricusbisporus) implications for film permeability in modified atmosphere packages. J. Food Sci., 72, 197-204. 
Crowe, K.M., Bushway, A.A. and Bushway, R.J. (2005) Effects of alternative postharvest treatments on the microbiological quality of lowbush blueberries.Small Fruits Review, 4 (3), 29-39.

Das, P.K., Hassan, M.K. and Akhther, N. (2010)Efficacy of washing and postharvest treatments on shelf life and quality of oyster mushroom. Progress. Agric., 21 (1\&2), $21-29$.

Ding, P. and Ling, Y.S. (2014) Browning assessment methods and polyphenol oxidase in UV-C irradiated Berangan banana fruit. International Food Research J., 21 (4), $1667-$ 1674 .

FAO (2009) Make money by growing mushrooms, Rome. http://www.fao.org/3/ai0522e.pdf.

Farber, J.N., Harris, L.J., Parish, M.E.,Beuchat, L.R.,Suslow, T.V., Gorney, J.R., Garrett, E.H. and Busta, F.F. (2003) Microbiological safety of controlled and modified atmosphere packaging of fresh and fresh-cut produce. Comprehensive Reviews in Food Science and Food Safety, 2, 142-160.

FDA (1998) "Bacteriological Analytical Manual", $8^{\text {th }}$ ed. Association of Official Analytical Chemists. Maryland: AOAC International.

Forney, C.F.,Rij, R.E., Dennis-Arrue, R. and Smilanick, J.L. (1991) Vapor phase hydrogen peroxide inhibits post-harvest decay of table grapes. Hort. Sci., 26 (12), $1512-1514$.

Hammond, J.B.W. (1979) Changes in composition of harvested mushrooms (Agaricusbisporus).Phytochem., 18 (3), 415-418.

Hammond, J.B.W. and Nicholas, R. (1975) Changes in respiration and soluble carbohydrates during the post-harvest storage of mushrooms (Agaricusbisporus) .J. Sci. Food Agri., 26, 835-842.

Hu, X., Bidney, D.L.,Yalpani, N., Duvick, J.P., Crasta, O.,Folkerts, O. and Lu, G. (2003) Overexpression of a gene encoding hydrogen peroxide-generating oxalate oxidase evokes defense responses in sunflower. Plant Physiol., 133, 170-181.

Jiang, T., Jahangir, M.M., Lu, X. and Ying, T. (2010) Influence of UV-C treatment on antioxidant capacity, antioxidant enzyme activity and texture of postharvest shiitake (Lentinusedodes) mushrooms during storage. Posth. Biol. Technol., 56, 209-215.

Jolivet, S., Arpin, N., Wicher, H.J. and Pellon, G. (1998) Agaricusbisporus browning: a review. Mycol. Res., 102, 59-83.

Juven, B.J. and Pierson, M.D. (1996) Antibacterial effects of hydrogen peroxide and methods for its detection and quantitation. J. Food Prot., 59 (11), 1233-1241.

Kaya, C., H. Kirnak, D. Higgs and K. Saltali (2002) Supplementary calcium enhances plant growth and fruit and fruit yield in strawberry cultivars grown at high $(\mathrm{NaCl})$ salinity. Scientia Hort., 93, 65-74.

Egypt. J. Hort. Vol. 43, No.1 (2016) 
Lagnika, C., M. Zhang, J. Nsor-Atindana, and F. Tounkara (2014) Extension of mushroom shelf-life by ultrasound treatment combined with high pressure argon. Int. Agrophys., 28, 39-47.

Lespinard, A.R., S.M. Goni, P.R. Salgado and R.H. Mascheroni (2009) Experimental determination and modelling of size variation, heat transfer and quality indexes during mushroom blanching. J. Food Eng., 92, 8-17.

Li, T., M. Zhang and Wang, S. (2008) Effects of temperature on Agrocybechaxingu quality stored in modified atmosphere packages with silicon gum film windows. $L W T$, 41, 965-973.

Martin, H. and Maris, P. (2012) Synergism between hydrogen peroxide and seven acids against six bacterial strains. J. Appl. Microbiol.,113, 578-590.

Mohapatra, D., Frías, J.M., Oliveira, F.A.R., Bira, Z.M. and Kerry, J. (2008) Development and validation of a model to predict enzymatic activity during storage of cultivated mushrooms (Agaricusbisporus) J. Food Eng., 86, 39-48.

Mohapatra, D., Z.M. Bira, J.P. Kerry, J.M. Fríasand F.A. Rodrigues (2010) Postharvest hardness and color evolution of white button mushrooms (Agaricusbisporus). J. Food Sci., 75 (3), E146-152.

Neill, S.J., Desikan, R. and Hancock, J. (2002) Hydrogen peroxide signaling. Curr. Opin. Plant Biol., 5, 388-395.

Nerya, O., Ben-Arie, R., Danai, O., Tamir, S. and Vaya, J. (2005) Inhibition of mushroom browning. Acta Hort. (ISHS), 682, 1885-1888.

Osuga, D., van der Schaaf, A. and Whitaker, J.R. (1994) Protein Structure-Function Relationships in Foods,Yada, R.Y., Jackman, R.L. and Smith, J.L., (Ed.), Blackie Academic \& Professional: Glasgow, pp. 62-88.

Peng, L., Yang, S., Li, Q., Jiang, Y. and Joyce, D.C. (2008) Hydrogen peroxide treatments inhibit the browning of fresh-cut Chinese water chestnut. Postharvest Biol. and Techn., 47 (2), 260-266.

Quan, L.J., Zhang, B., Shi, W.W. and Li, H.Y. (2008) Hydrogen peroxide in plants: a versatile molecule of the reactive oxygen species network. J. Integr. Plant Biol., 50, $2-16$.

Raffellini, S., Guerrero, S. and Alzamora, S.M. (2008) Effect of hydrogen peroxide concentration and $\mathrm{pH}$ on inactivation kinetics of Escherichia coli. J. Food Safety, 28, $514-533$.

Rai, R.D. and Saxena, S. (1989) Biochemical changes during postharvest storage of button mushroom (Agaricusbisporus). Current Sci.,58, 508-510.

Rai, R.D. and Arumuganathan, T. (2008) Postharvest technology of mushrooms. Tech. bull., National Research Centre for Mushroom (ICAR) Chambaghat, Solan -173213 (HP), India.nrcmushroom.org/Bull_PHT.pdf. 
Ruangchakpet, A. and T. Sajjaanantakul (2007) Effect of browning on total phenolic, flavonoid content and antioxidant activity in Indian gooseberry (Phyllanthusemblica Linn.). Kasetsart J. (Natural Sci.) 41, 331-337.

Saltveit, M.E. (2002) The rate of ion leakage from chilling-sensitive tissue does not immediately increase upon exposure to chilling temperatures. Postharvest Biol. Technol., 26, 295-304.

Sapers, G.M. and Simmons, G.F. (1998)Hydrogen peroxide disinfection of minimally processed fruits and vegetables. Food Technol.,52(2), 48-52.

Sokal, R.R. and Rohlf, F.J. (1995) "Biometery", $3^{\text {rd }}$ ed. Freeman, San Francisco, CA.,887p.

Swaminathan, M. (1988) Browning reactions in foods. In: "Handbook of Food Science and Experimental Foods". The Bangalore Printing and Publishing Co. Ltd, Bangalore, pp. 89-91.

Tao, F., Zhang, M., Yu, H.Q. and Sun, J.C. (2006) Effects of different storage conditions on chemical and physical properties of white mushrooms after vacuum cooling. J. Food Eng., 77, 545-549.

Ukuku, D.O., Bari, M.L., Kgwamoto, S. and Isshiki, K. (2005) Use hydrogen peroxide in combination with nisin, sodium lactate and citric acid for reducing transfer of bacterial pathogen from whole melon surfaces to fresh cut pieces. Int. J. Food Microbial., 104, 225-233.

Urszula, M. and Rozalska, S. (2005) Nitric Oxide and hydrogen peroxide in tomato resistance: Nitric oxide modulates hydrogen peroxide level in O-hydroxyethylorutininduced resistance to Botrytis cinerea in tomato. PlantPhysiol and Bioch.,43, 623-635.

Van Breusegem, F., Vranova, E., Dat, J.F. and Inze, D. (2001) The role of active oxygen species in plant signal transtrction. Plant Sci.,161, 405-414.

Vizhanyo, T. and Felföldi, J. (2000) Enhancing colour differences in images of diseased mushrooms.Comp. Elec. Agric., 26, 187-198.

Walker, J.T. and Marsh, P.D. (2007) Microbial bio-film formation in DUWS and their control using disinfectants. J. Dent., 35, 721-730.

Wells, J.M., Sapers, G.M., Fett, W.F., Butterfield, J.E., Jones, J.B., Bouzar, H. and Miller, F.C. (1996) Postharvest discoloration of the cultivated mushroom Agricusbisporus caused by Pseudomonas tallaasii, 'P. reactans' and 'P. gingeri'. Phytopathology, 1098-1104.

Zivanovic, S. and Buescher, R. (2004)Changes in mushroom texture and cell wall composition as affected by thermal processing. J. Food Sci., 69(1), 44-49. 


\section{فعالية فوق أكسيد الهيدروجين فى جودة مشروم الأجاريكس الأبيض بعد الحصاد

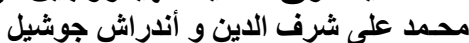

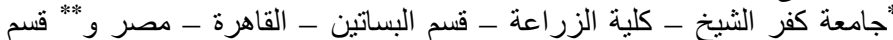

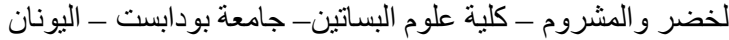

يفقد المشروم جودته سريعا نتيجة حساسيته للتلون البنى، وتدهور مكوناته،

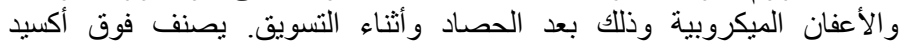

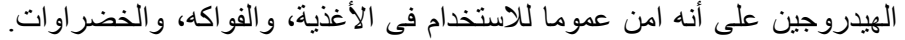

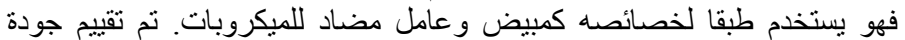

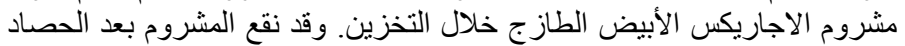

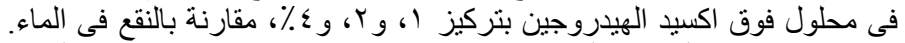

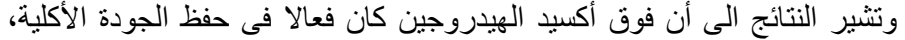

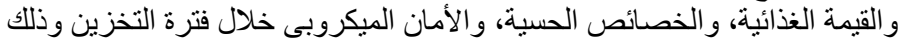

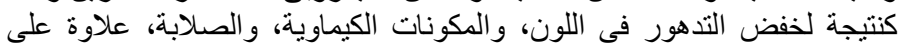

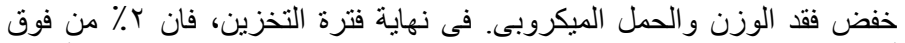

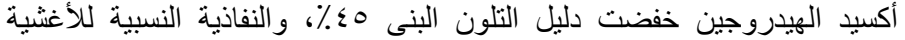

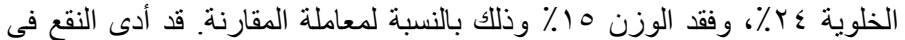

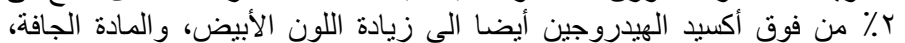

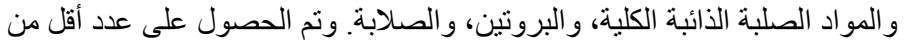

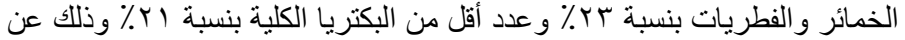

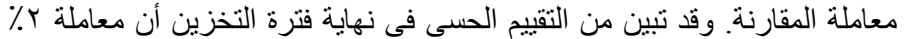

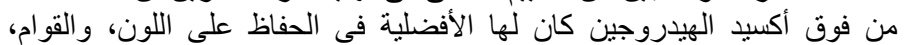
و المظهر العام وذلك بالنسبة لمعاملة المقارنة. 